\title{
THE CONCEPT OF CHINA'S PEACEFUL RISE AND OFFENSIVE REALISM
}

The continuous rise of China for over four decades has caused a major shift in the world balance of power. As a result, the global order has shifted from unipolarity to bipolarity. ${ }^{1}$ The growth of China and its influence upon the US led world order can be compared to the collision of tectonic plates. The exact outcome of this collision is still yet to be determined. However, some scholars believe that a peaceful rise of China is not only desirable and possible but also is happening right now. This article argues that according to the offensive realist theory the likelihood of the aforementioned presuppositions is rather thin, if not impossible.

The paper is organized as follows: firstly, I lay out the main assumptions of offensive realism and regional hegemony. Secondly, I discuss the theory of "China's peaceful rise" and I argue that it smoothly overlapped with the US strategy of liberal hegemony. Thirdly, I present and defend my argument that China does not rise peacefully. Furthermore, China wants to became a regional hegemon in South-East Asia and the USA according to offensive realism cannot let it happen. Fourthly, I consider the arguments that are frequently used to support the theory of "China's peaceful rise" and explain why they fail to depict the current and predict the future nature of US-China relations. Finally, I sum up the findings of the previous sections and examine why the concept of the peaceful rise of China is not in accordance with the realist paradigm.

\section{OFFENSIVE REALISM}

Offensive realism is a sub theory in international relations. It belongs to the neorealist school of thought. The theory was put forward by John J. Mearsheimer as a re-

\footnotetext{
${ }^{1}$ Although John J. Mearsheimer's argument is that the structure of the world system is multipolar and comprising of three great powers: the United States, China and Russia (Mearsheimer, 2014: 398-399); in my opinion the way John Mearsheimer qualifies states as great powers is not crystal clear. He categorises Russia with its economy roughly the size of Italy (Russian GDP in $2020-1.4$ trillion \$, whereas Italian GDP in 2020 - 1.8 trillion \$), as a great power, while e.g., India (GDP in 2020 -2.5 trillion \$) is not listed as a great power. Moreover, both great powers, the USA and China, possess economies more than ten times bigger than Russia, 20.8 trillion $\$$ and 15.2 trillion $\$$ respectively (Projected GDP ranking) Furthermore, similar power gap can be seen while comparing defense budgets. The military spending of the USA and China surpass Russian military spending by one order of magnitude, 730 billion \$ of US and 261 billion \$ of Chinese military spending against 65.1 billion \$ Russian military spending in 2019 (Countries with the highest military spending worldwide in 2020). That is why in my view, the world order in 2021 is bipolar and there are only two great powers, namely, the USA and China.
} 
sponse to defensive realism. Defensive realism is a concept created by Kenneth Waltz. The latter based its theory on the same starting assumptions as John J. Mearsheimer but reaches different conclusions. The former states that in the anarchical system there is a repeated pattern of balancing coalitions of weaker states against a rising power, the bidder for hegemony. According to defensive realism, the balancing ought to prevent states from pursuing hegemony as it would be tantamount to a war against a mighty coalition and almost inevitable defeat of the emerging power. In other words, defensive realism claims that the anarchical system encourages states to behave in a defensive manner protecting the status quo rather than challenging it (Waltz, 2010: 113-116; Steinsson, 2014: 2).

The Offensive realist theory assumes that the international system is anarchic. It means there is no higher authority that sits above states to call upon if trouble comes. Hence, the world system is a self-help and highly competitive environment (Mearsheimer, 2014: 30). The main actors in the system are great powers because these states have the greatest agency and shape the world order, whereas other states an non-state actors play significantly minor role (Mearsheimer, 2014: 5-6). According to offensive realism great power politics is a zero-sum game. The increase in power and, at the same time, the boost to the sense of security of one state means relative weakening and the erosion of the sense of security of other states in the system. First amongst neighbouring states, subsequently amongst other states in the system (Mearsheimer, 2010: 386). Therefore, this process may result in an arms race.

Offensive realists claim that the most important objective for any state is survival. If a state fail to survive, it can hardly ever pursue any other goals (Mearsheimer, 2014: 3 ). The best way to ensure the utmost sense of security of any state is to maximize its share of world power and finally achieve regional hegemony (Mearsheimer, 2014: 31, 33-36).

Offensive realism presumes that in the anarchical system when a state becomes an economic power it will almost inevitably transfer it into military strength. Although, there are some exceptions to this principle, e.g., united Germany after 1990, but it happened mostly because of the geopolitical environment of West Europe: almost nonexistent security competition within the EU and the US military presence in Europe and ipso facto, the exceptions prove the rule (Allison, 2018: 42, 283-286).

Moreover, after transfering its economic power into military might, a state will finally seek regional hegemony the same way the USA did in the western hemisphere, because it is the most certain way to survive (Mearsheimer, 2014: 2). Having achieved regional hegemony a great power tries to prevent other powers from achieving that status the exact way the USA did in the $20^{\text {th }}$ century (Mearsheimer, 2014: 140-141). China is no exception to this rule. Seeking its national security China is looking forward to achieving regional hegemony from sound strategic reasons. Furthermore, the acquisition of regional hegemony is in all likelihood the most certain way to get Taiwan back (Mearsheimer, 2010: 389), which is a crucial goal in the pursuit of Xi Jinping's „the great renaissance of the Chinese nation" (Góralczyk, 2018: 323-326, 359, 362-365).

Offensive realists in contrary to defensive realists assert that the international system delivers an abundance of incentives for states to behave aggressively and maximize their share of word power. By striving for extra power states simultaneously 
increase their odds of survival (Mearsheimer, 2014: 20-21). ${ }^{2}$ In other words powers seek regional hegemony out of pure logic and reason, pursuing the key goal of any state, its survival, not because of their malign intentions.

Since 1783 and its victory over the UK, the USA all over the $19^{\text {th }}$ century was well on its way to establishing hegemony in the western hemisphere and finally did it after defeating Spain in 1898. In the $20^{\text {th }}$ century the United States fought and defeated four potential peer competitors to regional hegemony in Eurasia: Imperial Germany, Nazi Germany, Imperial Japan, and the Soviet Union (Mearsheimer, 2014: 364-367). I would add to this list of the United States' potential peer competitors a case study of Japan in 1980s. Japan at the time was one of the world's fastest-developing states and its economy was on course to outperform the US economy. Japan's rapid economic growth was suppressed by the Plaza Accord in September 1985. Japan agreed to appreciate its currency relative to the U.S. dollar. As a result, its export and GDP growth basically halted, and Japan entered a period of long-running economic recession often called "Lost Decade" (Obstfeld, 2009).

John J. Mearsheimer claims that the best result that a great power can achieve is the status of a regional hegemon. It means to be by far the most powerful state in the region with a huge power gap between it and the second powerful state in the region. Moreover, the power gap is so immense that even a coalition of neighboring states would not dare pick a fight with a regional hegemon (Mearsheimer, 2014: 387-388).

According to offensive realism global hegemony is virtually impossible to achieve due to the difficulty of projecting power across vast bodies of water like the Pacific Ocean (Mearsheimer, 2014: 387).

According to the offensive realism theory the United States is bound to go to great lengths to beat China, Not necessarily by a military action, and prevent it from gaining regional hegemony in South-East Asia (Mearsheimer, 2010: 390). If the USA fails to do so, the consequences for the US led world order will be dire (Mearsheimer, 2014: 40-42). Once having established its hegemony in the region, without security competition with already subordinated neighboring powers, China will be free to roam in South-East Asia. Moreover, armed with a blue water navy China will be capable of projecting power all over the planet, exactly the same way the USA has been acting at least since 1898 when it beat Spain and became unchallenged hegemon in the Western Hemisphere (Miyake, 2017; Mearsheimer, 2014: 379-380).

Over 40-year- long, unstopped and constant Chinese economic rise (the World Bank data) has delivered the author a sufficient body of evidence to assume that China is going to grow economically in the foreseeable future, although not as rapidly as it used to in previous years. A GDP annual growth rate of $3-4 \%$ in the following years is most probable, though the estimated Chinese economy forecast for 2021 is about $8 \%$ (Cheng, 2020). But even if Chinese economy from some sudden and unexpected reasons went flat, China is already posing a genuine and imminent threat to the US led world order (Mearsheimer, White, 2019). The threat much larger than anything that the USA had to challenge in the

${ }^{2}$ But, nota bene, the list of powers that preferred maintaining status quo instead of changing it is also quite long e.g., the Polish-Lithuanian Commonwealth in most of the 16th and 17th century, the Habsburg Empire, through most of the $18^{\text {th }}$ and 19th century; for a short summary of the foreign affairs of the Polish-Lithuanian Commonwealth (Davies, 2005; Sediv'y, 2013). 
$20^{\text {th }}$ century. During the Cold War the GDP of the Soviet Union at its height reached only $40 \%$ of the size of the US economy (Mahbubani, 2020: 4). In 2020 Chinese economy accounted for $71.4 \%$ of U.S. GDP (nominal), whereas in purchasing power parity (PPP) terms China already surpassed the USA in 2014 (Cooley, Nexon, 2020: 3).

If China continues to improve its workforce productivity and I believe it does, with its 1.442 bn (Worldometers, 2021) population, in comparison to the US population - 332 mil (Worldometers, 2021), China does not have to reach the US workforce productivity to become a far much larger economy than the US in the following years. ${ }^{3}$ Having achieved that growth in workforce productivity in the foreseeable future, China will transform itself into an unstoppable economic and military giant capable of operating globally.

That is why the USA to maintain its hegemonic position in the western hemisphere and the US led world order cannot let this happen and ought to stop the rise of China.

\section{THE THEORY OF "CHINA"S PEACEFUL RISE" AND LIBERAL HEGEMONY}

It is time to consider the term "China's peaceful rise" (heping jueqi) was coined and first used by Zheng Bijian in 2003. He is a Chinese politician, thinker, and multiannual advisor of China's top officials. During his long career (he was born in 1932), has been in the Chinese Communist Party's (CCP) institutions since early 1950s, he was a close associate of many Chinese leaders e.g., Hu Yaobang, Zhao Ziyang, Ziang Zemin, Hu Jintao. Zheng Bijian, during his long political career held many important posts. From 1992-1997 he served as deputy director of The Publicity Department of the Central Committee of the Chinese Communist Party. The department is commonly called the Propaganda Department (Suettinger, 2004: 1-2).

"China's peaceful rise" theory was conceived as a Chinese response, and a way to disarm Western fledging concerns caused by the staggering growth of Chinese economy might after 1978. By propagating the term, China wanted to efficaciously address the issue of "China threat", both in the United Stated and in South-East Asia. "China's peaceful rise" theory states that China in contrary to other historical emerging powers e.g. Imperial Germany, Nazi Germany, Imperial Japan or the Soviet Union (namely former US would be peer competitors), does not seek its development via violent confronting world order and revision of the status quo.

Instead, China pledged to take a new path based on mutual benefit and reciprocity in globalizing trade, opened domestic markets, structural adjustment and common prosperity in South-East Asia. According to "China's peaceful rise" theory US-China relations ought to rely on constructive dialogue and close cooperation. Since the concept assumes that China wants to integrate itself into the world order, not challenging

${ }^{3}$ Chinese workforce productivity per hour in 2018 amounted to $15 \$$, whereas US workforce productivity per hour in 2018 amounted to $105 \$$ (Countries with the highest military spending worldwide in 2020). Hence if Chinese workforce continues to grow and in the years ahead reaches the workforce productivity of e.g., South Korea $(39.6 \$$ per hour (Countries with the highest military spending worldwide in 2020) the Chinese economy is going to be much larger than the US economy. 
it, in Zheng Bijian's theory there is not a single mention about the US-China strategic rivalry (Bijian, 2005: 10-11, 22-23).

Having that stated I am going to analyze how much "China's peaceful rise" theory overlapped with the grand strategy that the USA adopted in foreign policy about 1990, commonly known as "liberal hegemony". The world order after the collapse of the Soviet Union shifted from bipolarity into unipolarity. The "unipolar moment" (Krauthammer, 1990-91: 22-23), that started around 1990, heralded the new US approach to IR. The United States was the most powerful state on the globe, with a tremendous power gap between it and other powers. In fact, the US was the only great power in the system and could adopt its new foreign policy approach literally at will. There was no other great power to oppose it. The US chose "liberal hegemony," which shaped the US foreign policy between 1990-2017. This strategy had three major aims. Firstly, to alter as many states as possible into liberal democracies. Secondly, to create an open, liberal and global economy, based on free market and free flows of people and capital. Thirdly, to build a universalistic rules-based world order in which states are embedded in international institutions e.g. WTO, the UN, the EU (Mearsheimer, 2018: 188). The United States serving as a beacon of liberal values, was the leader of the global system.

Liberal hegemony was predicated upon the democratic peace theory. The theory states that liberal democracies do not fight each other nor extensively break human rights. The roots of the democratic peace theory derive from Immanuel Kant's work: Perpetual Peace (1795). The theory is rather poorly proved, mostly due to too limited number of democracies. According to Freedom House Still in 1973 there were merely 45 "free" states out of total 151 states in the world (Fukuyama, 2012:3). That is why by settling the world with nothing but law-abiding liberal democracies, it was hoped there would be neither inter-state military conflicts nor massive human rights violations. The fate of US-led liberal world order was sealed - worldwide peace and prosperity, the end of history has come.

After 1990, the USA was deeply committed to liberal hegemony. The United States Armed Forces have been involved in innumerable military conflicts. But instead of spreading democracy and human rights on the globe, it caused much instability in many areas. So called the Bush Doctrine is probably the most exemplary case of practical implementation of liberal hegemony and its missionary zeal. It turned out that waging war against home grown terrorism and nationalism-driven insurgency while doing nation-building social engineering is a mission next to impossible, ended up wreaking havoc in the vast areas of the greater Middle East (Mearsheimer, 2018: 153-155).

Not surprisingly, the case of China has shown that the lure of liberal order and democracy can be less attractive than the US foreign policy establishment had thought. Unfortunately, the USA, in pursuing liberal hegemony, underestimated the role of two powerful factors, namely, sovereignty and nationalism (Mearsheimer, 2018: 118-122). Both of them were thought to be obsolete and so much from the ancien regime. Therefore, not up to "the end of history" and the new liberal world order. As a result, China has become an incredibly rich and prosperous state, ${ }^{4}$ but it did not liberalize its politi-

${ }^{4}$ According to The World Factbook, compiled by CIA, China in 2021 has the world's largest economy with a GDP (PPP) of approximately $\$ 25.360$ trillion, whereas the USA, at number two position with a GDP of approximately $\$ 19.490$ trillion. 
cal institutions. Furthermore, China in recent years has taken even more authoritarian style of government. Arguably Xi Jinping has amassed more power than any other Chinese ruler since the death of Mao in 1976. The more authoritarian China gets the less transparent and low abiding it becomes (Góralczyk, 2018: 351-355).

In addition, the rise of China in contrary to Zheng Bijian's claims has neither created a prosperity economic zone based on win-win policy nor led its foreign politics built on constructive dialogue and close cooperation with both neighbours and the USA. Zheng Bijian in one of his speeches stated: „I am very pleased to see the new cooperative relationship of mutual promotion, mutual benefit, mutual support, and complementarity forged between China and other Asian countries." (Bijian, 2005: 17). The outcome for many Chinese partners in Asia rendered to be far less positive than Zheng Bijian had foreseen. The One Belt One Road initiative instead of development and prosperity has misled many Asian states to fall into Chinese debt-trap (Ferchen, Perera, 2019).

From the American view point the Belt and Road Initiative serves China as a massive geopolitical scheme, aimed at gaining strategical economic supremacy in Asia. That is why the USA has devised the Blue Dot Network, an initiative, which main goals are counter balancing Chinese influences in the Indo-Pacific region, providing assessment and certification of infrastructure development projects and lust but not least mobilizing private capital to invest in the region (Geraci, Cooper, $\mathrm{Li}, 2020$ ).

\section{NON-PEACEFUL RISE OF CHINA}

The term "China's peaceful rise" is even less adequate in describing the real character of rising China when we examine briefly current Chinese foreign policy under Xi Jinping. About 2009 China had dropped Deng Xiaoping's astute and smart foreign policy pattern of keeping a low profile and not causing anxiety amongst South-Asian states by its rising economic and military might.

After 2009 China commenced employing more assertive, aggressive and even warlike stance (Mearsheimer, 2014: 380-383). This new pattern of Chinese diplomatic philosophy is often called „Wolf warrior diplomacy” (Cheng, 2020), which refers to its aggressive and self confident style. As a consequence, since approximately 2009 and definitevly after 2012/13 (Brown, 2017: 90-97) Chinese relations with neighbouring states have deteriorated substantially. In 2020 (Green, 2020; Dalton, Zhao, 2020) and 2021 (Ellis-Petersen, 2021) China and India engaged in skirmishes over the disputed areas along the Sino-Indian border, called the „Line of Actual Control” (LAC). The mentioned standoffs have been the graviest Sino-Indian military clashes in fifty years.

At the same time Chinese-Australian relations also have quicly worsened. China's growing political and economic influence along with tensions over „COVID-19 diplomacy”, especially as a Chinese aggressive response to Australian government's calls for an independent investigation into the causes of the pandemic COVID-19 in China (Laurenceson, Zhou, 2020) and existing Chinese espionage network in Australia (Hamilton, 2018), have caused barely-veiled Chinese threats and one-sided Chinese trade war against Australia (Nagy, 2020; Russell, 2021). 
Moreover, under Xi Jinping China's increasingly assertive foreign policy has caused territorial disputes with almost all of its neighbours. China claims sovereignty over Taiwan, perceiving it as a breakaway province that will be reunited with the PRC, manu militari if need be. The present Taiwanese government, however, sees itself a sovereign state and has no intention of becoming a reunited Chinese province.

Furthermore, China has long-lasting territorial disputes with Brunei, Malaysia, the Philippines, Taiwan and Vietnam over the Spratly Islands, the archipelago in the South China Sea, and with Vietnam over the Paracel Islands, the archipelago, which is also located in the South China Sea (Mearsheimer, 2014: 375).

Another disputed territory in the region is Scarborough Shoal, which is a chain of reefs and rocks in the South China Sea. The sovereignty over Scarborough Shoal is claimed by China, Taiwan and the Philippines (Dossani, Harold, 2016; Rosen, 2014). In addition, in the East China Sea, China has another disputed territory - the Senkaku Islands (Japanese term), or Diaoyu Islands (Chinese term), over which China, Taiwan and Japan claim sovereignty (Lohmeyer, 2008; Sato: 2019).

In addition, China has deteriorated its relation with its neighbours by militarization of the disputed chains of islands. The military build up consists in substantial enlargement of Chinese Navy (PLAN), Chinese Air Force (PLAAF), Chinese Coast Guard (CCG) and its Marine Corps (PLANMC). To make matters worse, China conducts naval and air force exercises and sovereignty patrols of the disputed area, carries on runway extension work, the deployment of a diverse array of anti-access/area denial (A2AD) capabilities and deepens its port facilities.

Furthermore, China has recently fortified multiple forward operating bases with anti-ship cruise missiles (ASCMs) and surface-to-air missiles (SAMs) along with underground storage facilities, aircraft hangars, radars, and sensor arrays and upgraded or newly built military facilities (Grossman, 2020: 183-187).

In recent years the growing Chinese military presence in South-East Asia, inhenced by the "security dilemma," has created a sense of insecurity and fear amongs the USA and Chinese neighbours. The historical record plainly showed the way the USA routinly reacted upon any bids for hegemony. Whenever a peer cpmpetitor appeared the USA formed a mighty balancing coalition in order to contain and roll back the revisionist rising power (Mearsheimer, 2014: 383-384). In 2017 as a response to Chinese bellicose and aggressive behaviour in the South-Asia region, the USA decided to revise and transform the already existing forum "Quadrilateral Security Dialogue (Quad)" into a new updated "Quad 2.0". This could be a first step into building a US-led balancing coalition against China or even changing the existing arrangement into a new alignment aiming at initiating a "rules-based" order in the Indo-Pacific (Smith, 2020) and eventually establishing an "Asian NATO" (Park, 2020).

In 2020 "Quad 2.0" meeting was not only joined by the representatives of the USA, India, Australia, and Japan but also by the representation of three additional regional powers: New Zealand, South Korea and Vietnam (Rajagopalan, 2020: 3).

It is important to mention, that the already stated recent anti-Chinese turn is visible not only among policy makers but also among the societies of the Ind-Pacific region.

${ }^{5}$ "Quad 1.0" was initiated in 2007 by Japanese Prime Minister Shinzo Abe and consisted of 4 members, Japan, the USA, India and Australia (Envall, 2019: 1,5). 
It is caused partly by China's aggressive foreign policy and partly by rude and nationalistic activity of Chinese trolls and chauvinistic comments on social media. These resulted in formation of anti-Chinese and pro-democratic movements. One of such anti-Beijing online movements is the Milk Tea Alliance. In South-East Asia milk tea is perceived as an anti-China symbol because in many states in the region, in contrast to China, tea is traditionally consumed with milk (Mclaughlin, 2020).

\section{THE ECONOMIC INTERDEPENDENCE THEORY AND “CHINA'S ANTIMILIOTARISM THEORY”}

Given the dynamics of the rising Chinese threat in the Indo-Pacific region it is surprising that the sheer concept of "China's peaceful rise" is still strongly advocated by so many opinion-forming scholars. A number of acclaimed academicians, such as Henry Kissinger (Kissinger, 2011: 508-513), Kishore Mahbubani (Mahbubani, 2020: 85-89), Joseph Nye Jr (Nye, 2010: 146-149), Robert B. Zoellick (Zoellick, 2005), just to name a few, regardless of the already presented facts, still claim that China rises peacefully and poses no major threat to the world order.

In this subsection I am going to analyze two arguments that are routinely used to support the "China's peaceful rise" theory. The first one states that the Chinese civilization and as a result Chinese history and legacy are almost by definition peaceful and marked by Confucius based "the powerful antimilitary DNA of Chinese civilization" (Mahbubani, 2020: 83). I have called his particular approach "China's antimilitarism theory". The second frequently used argument is predicated upon the economic interdependence theory.

One of the strongest supporters of the theory of "China's peaceful rise" are Henry Kissinger and Kishore Mahbubani. Both of them routinely use "China's antimilitarism theory" in order to support their lines of argument. The former, strongly believes in "China's peaceful rise theory to that extend that whenever in the last chapter of his work (chapter 18), he touches upon the question of Chinese rise, he always adds the adjective "peaceful" or the adverb "peacefully" only the term "rise" is sometimes replaced by a less worrying term "development" (Kissinger, 2010: 508-513).

The latter, while trying to answer the question: "Is China expansionist?", writes about "the powerful antimilitary DNA of Chinese civilization". The roots of this "antimilitary Chinese DNA" Mahbubani derives from Confucius (Mahbubani, 2020: 85-86). This term is hardly applicable to Chinese civilization at the most basic level. Just between $1100 \mathrm{BC}$ and $1911 \mathrm{CE}$ China waged 3790 wars, which gives as 1.26 wars a year (Mosher, 2007: 55). These statistics appear to offer strong confirmation of aggressive nature of Chinese civilization. However, Kishore Mahbubani tries to reject these claims, arguing that if Chinese civilization was "inherently militaristic," as for many centuries the most powerful state in Eurasia, China would have conquered overseas territories in the region, such as Australia. ${ }^{6}$ Since China failed to do so, Kishore Mahbubani states that the concept of the "inherently militaristic" Chinese civilization is

${ }^{6}$ Kishore Mahbubani seems to forget about Chinese attempts to conquer Japan in the13th CE (Turnbull, 2010). 
erroneous. Moreover, Kishore Mahbubani uses an "inherently militaristic" quantifier to facilitate his argumentation: it is far easier to claim that a state is not "inherently militaristic" than just "militaristic."

There is one major flaw in Kishore Mahbubani's argumentation. It lies in its self-evident simplification of reality and overlooking geographical differences. Kishore Mahbubani appears to forget that often times in history, even "inherently militaristic" empires (let alone "just" militaristic ones) made decisions against annexation of foreign territories. ${ }^{7}$ The sheer fact of being the strongest power in the region and yet not conquering overseas lands in the neighborhood, does not mean a power is pacifistic by nature. That is why one could use Mahbubani's argument and say that the USA in the $19^{\text {th }}$ century wasn't an "inherently militaristic" power because despite being the strongest state in the Western Hemisphere, it did not seize e.g., the Caribbean. The USA did not conquer the Caribbean in the mid-19 $19^{\text {th }}$ century because of domestic affairs, mostly because of the slavery issue which resulted in the congressional stalemate over going south. The frictions between North and South inter alia over this matter was finally solved during the American Civil War (1861-65) (Mearsheimer, 2014: 238-247). Since the USA did not conquer the Caribbean region even though it could have, one could not jump to a conclusion that the USA in the 19th or 20th centuries was characterized by to use again Mahbubani's words (in which he depicts China) "The relatively peaceful streak" (Mahbubani, 2020: 85).

Hence only because China did not conquer Australia in the past while often being "the single strongest civilization in the Eurasian landmass" it doesn't render China a non-militaristic or non-expansionist power (Mahbubani, 2020: 82).

Moreover, Kishore Mahbubani also compares Chinese reluctance to conquer overseas territories with ruthless European colonial powers, such as Portugal, Spain and Great Britain (Mahbubani, 2020: 83-84). By doing so, Kishore Mahbubani seems to overlook geopolitical differences between China and three abovementioned European colonial powers. Portugal, Spain and Great Britain to expand abroad, had to go overseas. Portugal and Spain due to the peninsular geography, the communication boundary of the Pyrenees and a powerful French neighbourhood on the other side of the mountains and Great Britain due to its insular location.

Whereas China, situated in the Eurasian landmass, had more than enough room for manoeuvre and land military expansion. Furthermore, amphibious military operations are always categorized by a very high degree of risk (e.g., tides, weather, let alone overstretching of supply lines).

In sum, power projection over a large body of water is substantially more complicated than land warfare. Therefore, having a choice between land and naval warfare, Chinese leaders and commanders astutely tended to choose the former. ${ }^{8}$

${ }^{7}$ Like the Roman Empire after The Marcomannic Wars did not annex new territories in Central Europe due to its pacifistic modus operandi in international relations but because of domestic issues (Erdrich, Komoróczy, Madejski, Vlach, 2020).

${ }^{8}$ See planned invasions of Britain by Napoleon and Hitler and the complexity of Operation Overlord and D-Day in June 1944; for more general view, see Ishizu, 2014: 137-159; for the planned French invasion of Britain, see Philip, 2005; for the planned German operation Seelöwe (See Lion) (Forczyk, 2016). 
In addition, Kishore Mahbubani in his defense of China's non-violent legacy, states that if there was any Chinese expansion done manu militari, most of it took place while China was ruled by foreign dynasties. Therefore, the burden for military expansionism ought to be born by China's foreign rulers not China as a state itself (Mahbubani, 2020: 84). Following the same line of reasoning, one could say that the lion's share of Spanish and British colonial gains took place when both Spain and England were ruled by foreign dynasties $^{9}$ and ipso facto these states were non-militaristic but just fell under foreign dynasties' negative influences. Since we do not try to negate Spanish nor British militaristic stance in the modern age, we should not do this either to defend China and support the flawed and ahistorical "China's antimilitarism theory." In sum, under Closer scrutiny of Kishore Mahbubani's vision of Chinese civilization (Mahbubani, 2020: 79-104), it appears that the Han Chinese have somehow accidentally built their empire mostly by a mixture of Confucius based antimilitarism or foreign rulers (Mahbubani, 2020: 85-86), but not but a planned and steady ruthless conquest of neigbouring lands.

Although Kishore Mahbubani admits that the Chinese have fought many wars, at the same time he adds that most of them were within China. The problem with this line of reasoning is that it fails to recognize Chinese continuous territorial expansion to the North, West and South. So, from the perspective of present borders, most wars fought by China let say 2000 years ago, under Han dynasty, indeed happened within present-day Chinese territory, whereas Chinese state 2000 years ago was much smaller (Wu, Hein, Zhang, Jin, Wei, Huang, Yin, 2019: 6753).

The sad fact about empires in history is that they have always been built not upon "powerful antimilitary DNA", but ruthless wars, persistent and purposeful expansion and mercyless politics based on divide et impera strategy. China is no exception in that regard.

Let us now consider the second major argument that frequently supports the China's peaceful rise theory namely, the economic interdependence theory. It claims that the Chinese and US economies are so closely intertwined that any major disturbance would cause tremendous loss and mutual impoverishment. Hence nobody in their right mind would decide to cause that disturbance and kill the goose that lays the golden egg.

Unfortunately this argument has one major flaw, namely it has been used in the past and turned out to be completely wrong. The very same argument was used by Norman Angell before the WWI, in his work The Great Illusion (Angell, 1913: V-VIII, 144-155) where he claimed that waging war, especially caused by nationalism, in the age of close economic ties between European states, was obsolete and futile. Moreover, he argued that a general European war was very unlikely to start, and if it did, it would not last long. A modern war according to Angell was simply too costly and nationalism an obsolete notion. He was proved wrong.

An additional historical example that showed the shortcomings of economic interdependence theory is the Iraqi invasion of Kuwait in 1990. Saddam Hussein attacked Kuwait regardless of close economic ties with its oil-rich neighbour (Nonneman, 1996: 181-183). The same can be said about almost every single civil war in history

${ }^{9}$ Spain was ruled by the Habsburg dynasty over the $16^{\text {th }}$ and $17^{\text {th }}$ centuries whereas England and subsequently the United Kingdom was ruled by the Dutch and German dynasties since the $17^{\text {th }}$ century onwards (Elliot, 2006). 
where sizeable economic interdependence between the belligerents was self-evident (Mearsheimer, 2014: 408-409).

Needless to say, one state cannot know other state's present intentions let alone the future ones. That is why to gauge the likelihood of hostile intentions of other states in the modern and future USA-China relations we need a theory. Only a proper theory can help us predict the future US-China relations and verify whether China can rise peacefully in the future. In my opinion offensive realism is the first- class tool to analize great power politics and US-China relations are its textbook example.

There are two main factors that play a tremendous role in any threat intelligence in IR while states try to assess whether another state constitutes a threat. Namely, the capabilities and intentions of one's adversary (Mearsheimer, 2014: 31, 363). One of the key assumptions of offensive realism says that a state can never be certain of the intentions of other states. The intentions whether they are malign or benign stay hidden under the smoke screen of diplomacy political duplicity and ruse. That is why the real intentions of the other side are extremely difficult to measure and assess.

Since the aforementioned difficulties with assessment of the adversary's intentions (even present day ones let alone the future ones, in 10-20 years down the road) the intelligence officers have to focus on the assessment of the capabilities, which are far more tangible and easier to follow. But what happens when it turns out that the offensive capabilities of the potential adversary grow? Even though its today's intentions are ostensibly benign and peaceful, are they going to remain the same in the foreseeable future? What if not? Can a power like China or the USA base their national strategy on the assumption that their main adversary has no malign intentions and will not have ones in the years to come?

The offensive realist theory states that survival is the highest goal of every state (Mearsheimer, 2014: 46). If you do not survive you cannot pursuit any other goals. That is why a state that fears another state, starts growing up its military capabilities to match the capabilities of the latter and if it surpasses other competitors, it becomes a regional power and continues to grow because one can never be too powerful nor sure of the exact power of the adversaries. Even if a state is already by far the most powerful state in the region, it continues its military rise and tries to be stronger and stronger and achieve regional hegemony, because this is the best and the most certain way to survive and to became a fearless behemoth in the international system.

China, with its difficult history, having survived the "century of humiliation" due to its weakness between 1839-1949 (Wested, 2020: 32-33), surrounded by powers such as India, Japan, Russia and US naval bases in China's backyard, would be irrational not to pursuit hegemony in South-East Asia.

Hence seeking regional hegemony is tantamount to maximizing Chinese security. But on the other hand this course of action almost inevitably leads to a confrontation with the USA.

In conclusion, the previous pattern of US bid for regional hegemony alongside with the current increasingly aggressive Chinese foreign politics suggest the future perspective of the American intense security competition with China. 
It happened so in accordance with one of the main offensive realist concepts, namely, that in IR security almost always trumps prosperity. The rise of a great power nearly inevitably causes fear amongst its neighbours and other powers. The states fear for their safety and subsequently form a balancing coalition with the strongest status quo power in charge. This reaction defensive at its core raises the alarm in the revisionist rising power. The threat of encirclement makes it allocate even more funds into military spending regardless of trading ties with neighbouring states that now pose a menacing threat. Security almost always trumps prosperity.

As discussed above, the theory of China's peaceful rise is contradicted not only by the offensive realist theory, but also by practice, namely by the aggressive manner of Chinese foreign politics.

\section{REFERENCES}

Allison G. (2018), Destined for War, Can America and China Escape Thucydides's Trap, Scribe, Melbourne-London.

Angell N. (1913), The Great Illusion: A Study of the Relation of Military Power in Nations to Their Economic and Social Advantage, 3rd edition, G.P. Putnam's Sons, New York-London, https://www.gutenberg.org/files/38535/38535-h/38535-h.htm (01.03.2021).

Bijian Z. (2005), China's peaceful rise, Speeches of Zheng Bijian 1997-2005, Brookings Institution Press, Washington, https://www.brookings.edu/wp-content/uploads/2012/04/20050616bijian lunch.pdf (10.01.2021).

Brown K. (2017), CEO, China, The Rise of Xi Jinping, I.B. Tauris, London-New York.

Callahan B. (2015), John Mearsheimer and Joseph S. Nye Jr. on the rise of China and America's engagement policy, The Diplomat, https://thediplomat.com/2015/07/mearsheimer-vs-nyeon-the-rise-of-china/ (22.02.2021).

Cheng D. (2020), Challenging China's "Wolf Warrior" Diplomats, Backgrounder No. 3504, Asian Studies Center, https://www.heritage.org/sites/default/files/2020-07/BG3504.pdf (09.02.2021).

Cheng E. (2020), Fitch upgrades its China growth forecast for 2021, CNBC, https://www.cnbc. com/2020/12/10/fitch-upgrades-its-china-growth-forecast-for-2021.html (14.01.2021).

CNBC, https://www.cnbc.com/2020/12/10/fitch-upgrades-its-china-growth-forecast-for-2021.html (14.01.2021).

China: labor productivity per hour 2018, Statista, https://www.statista.com/statistics/878164/chinalabor-productivity-per-hour/ (29.12.2020).

China Population (2021), Worldometer, https://www.worldometers.info/world-population/chinapopulation/ (07.01.2021).

Cooley A., Nexon D. (2020), Exit from Hegemony: The Unraveling of the American Global Order, Oxford University Press, Oxford.

Countries with the highest military spending worldwide in 2020, https://www.statista.com/statistics/262742/countries-with-the-highest-military-spending/ 20.03.2021.

Dalton T., Zhao T. (2020), At a crossroads? China-India Nuclear Relations After the Border Clash, Carnegie Endowment For International Peace, https://carnegieendowment.org/2020/08/19/ at-crossroads-china-india-nuclear-relations-after-border-clash-pub-82489 (09.02.2021). 
Davies N. (2005), God's Playground: A History of Poland, Revised Edition, Volume 1: The Origins to 1795, Colambia University Press, New York, https://vk.com/doc278943367_496930103? hash $=$ fe75315e7ec8a6e81b (10.02.2021).

Dossani R., Harold S. W. (2016), Maritime Issues in the East and South China Seas. Summary of a Conference Held January 12-13, 2016, https:/www.rand.org/content/dam/rand/pubs/ conf_proceedings/CF300/CF358/RAND_CF358.pdf(16.02.2021).

Elliot J. H. (2006), Empires of the Atlantic world: Britain and Spain in America, 1492-1830, Yale University Press, New Haven, https://archive.org/details/empiresofatlanti00john/mode/2up, (01.03.2021).

Ellis-Petersen H. (2021), Indian troops brawl with Chinese counterparts on border, "The Guardian”, https://www.theguardian.com/world/2021/jan/25/india-soldiers-brawled-with-chinesecounterparts-on-border (09.02.2021).

Envall H. D. P. (2019), The quadrilateral security dialogue: Towards an Indo-Pacific Order? Policy Report, https://www.researchgate.net/publication/335880138_The_Quadrilateral_Security_ Dialogue_Towards_an_Indo-Pacific_order_Policy_Report_S_Rajaratnam_School_of_International_Studies (16.02.2021)

Erdrich M., Komoróczy B., Madejski P., Vlach M. (2020), Marcomannic Wars and Antonine Plague Selected essays on two disasters that shook the Roman World, Lubelskie Materiały Archeologiczne, Brno-Lublin, t. XVII, https://www.academia.edu/44538517/M Erdrich_B_Komor\%C3\%B3czy_P_Madejski_M_Vlach_eds_Marcomannic_Wars_and_ Antonine_Plague_Selected_essays_on_two_disasters_that_shook_the_Roman_World_ Die_Markomannenkriege_und_die_Antoninische_Pest_Ausgew\%C3\%A4hlte_Essays_zu_ zwei_Desastern_die_das_R\%C3\%B6mische_Reich_ersch\%C3\%BCtterten (01.03.2021).

Ferchen M., Perera A. (2019), Belt and Road Initiative. Why Unsustainable Chinese Infrastructure Deals Are a Two-Way Street, Carnegie - Tshingua Center for Global Policy, https:/carnegieendowment.org/files/7-15-19_Ferchen_Debt_Trap.pdf (09.02.2021).

Forczyk R. (2016), We March Against England: Operation See Lion, 1940-41, Osprey, Oxford, https://www.amazon.com/We-March-Against-England-Operation/dp/1472829832/ref= pd_sbs_2?pd_rd_w=QeDIG\&pf_rd_p=5e0f7f8d-f321-4a3e-bdac-3142fcd $848 \mathrm{~d} 7 \& \mathrm{pf}$ rd_r=Y5R87GYZRMPG4DB0XPE6\&pd_rd_r=7bc33191-e488-4b52-9f132f0fbab80d61\&pd_rd_wg=wzphD\&pd_rd_i $=1472829832 \& p s c=1(05.03 .2021)$.

Fukuyama F. (2012), The Origins of Political Order: from prehuman times to the French revolution, Profile Books, London.

Geraci M., Cooper A., Li M. (2020), Blue Dots and Red Roads, Frictions and the Potential for Limited Cooperation Between Chinese and U.S. International Development Models, Institute for China-America Studies, Washington, https://chinaus-icas.org/staging/6779/wp-content/ uploads/2020/07/Blue-Dots-and-Red-Roads.pdf (09.02.2021).

Green W. (2020), Conflict on the Sino-Indian Border: Background for Congress, U.S.-China Economic and Security Review Commission, https://www.uscc.gov/sites/default/files/2020-07/ Conflict_on_Sino-Indian_Border.pdf (09.02.2021).

Grossman D. (2020), Military Build-up in The South China Sea, The South China Sea: From a Regional Maritime Dispute to Geo-Strategic Competition, Routledge, RAND, London (19.02.2021).

Góralczyk B. (2018), Wielki renesans. Chińska transformacja i jej konsekwencje, Dialog, Warsaw. Hamilton C. (2018), Silent Invasion: China's Influence in Australia, Hardie Grant, Melbourne.

Ishizu T. (2014), Amphibious Warfare: Theory and Practice, 2014 International Forum on War History, http://www.nids.mod.go.jp/english/event/forum/pdf/2014/11.pdf (05.03.2021). 
Kant I. (1795), Perpetual Peace, https://www.researchgate.net/publication/303838832_Immanuel_ Kant's_Perpetual_Peace_The_New_World_Order_of_Critical_Philosophy $(05.01 .2021)$.

Kissinger H. (2011), On China, The Penguin Press, New York.

Krauthammer Ch. (1990-1991), The Unipolar Moment, "Foreign Affairs", Vol. 70, No. 1, America and the World 1990/91 (1990/1991), pp. 23-33, http://users.metu.edu.tr/utuba/Krauthammer. pdf (28.12.2020).

Laurenceson J., Zhou M. (2020), COVID-19 and the Australia-China relationship's zombie economic idea, Australia-China Relations Institute, Sydney, https://www.australiachinarelations. org/sites/default/files/20200507\%20Australia-China\%20Relations\%20Institute\%20report_ COVID-19\%20and\%20the\%20Australia-China\%20relationship\%E2\%80\%99s\%20zombie\%20economic\%20idea_James\%20Laurenceson\%20Michael\%20Zhou.pdf (16.02.2021).

Lohmeyer M. (2008), The Diaoyu / Senkaku Islands Dispute Questions of Sovereignty and Suggestions for Resolving the Dispute, University of Canterbury, Christchurch, https://ir.canterbury. ac.nz/bitstream/handle/10092/4085/thesis_fulltext.pdf;jsessionid=AE09BF0FF056D289412 D94F9FDD81C82? sequence=1 (16.02.2021).

Mahbubani K. (2020), Has China won? The Chinese Challenge to American Primacy, PublicAffairs, New York.

Mattingly D. C., Sundquist J. (2021), Public Diplomacy and Its Limits, https://static1.squarespace. com/static/51cdc7e5e4b0d7474642bcb0/t/600f8d8ffb5216ec2f0f69e/1611632020110/China_Public_Diplomacy_v3.pdf (09.02.2021).

Mclaughlin T. (2020), How Milk Tea Became an Anti-China Symbol, The Atlantic, https://www.theatlantic.com/international/archive/2020/10/milk-tea-alliance-anti-china/616658/(28.02.2021).

Mearsheimer J. J. (2010), The gathering storm, "The Chinese Journal of International Politics", Vol. 3, https://pdfs.semanticscholar.org/8cbe/90897f22a9ff2b4cfafb3e4900cfc089a3ad. pdf?_ga=2.188185952.911081758.1611195610-574350635.1598697473 (07.01.2021).

Mearsheimer J. J. (2014), The Tragedy of Great Power Politics, W.W. Norton \& Company, New York.

Mearsheimer J. J. (2018), The great delusion. Liberal dreams and international realities, CT: Yale University Press, New Haven.

Nagy S. R. (2020), Mitigating China's economic coercion, "The Japan Times", https://www.japantimes.co.jp/opinion/2020/05/21/commentary/mitigating-chinas-economic-coercion/ (16.02.2021).

Miyake K. (2017), China as a Middle East Power: The Pros and Cons of a More Assertive and Capable China in the Gulf and Beyond, Chia's Bluewater Navy Series, https://www.jstor. org/stable/pdf/resrep06119.pdf?refreqid=excelsior\%3A8f81f3d87a50e4c0fcd99b017ce71 $2 \mathrm{c} 7(02.01 .2021)$.

Mosher S. W. (2007), Hegemon. Droga Chin do dominacji, Sprawy Polityczne, Warsaw.

Nonneman G. (1996), The (Geo)political economy of Iraqi-Kuwaiti relations, Geopolitics and International Boundaries, https://www.researchgate.net/publication/233197307_The_Geopolitical_economy_of_Iraqi-Kuwaiti_relations (01.03.2021).

Nye J. S. Jr (2010), American and Chinese Power after the Financial Crisis, "The Washington Quarterly”, https://ciaotest.cc.columbia.edu/journals/twq/v33i4/f_0020821_17305.pdf (22.02.2021).

Obstfeld M. (2009), Time of Troubles: The Yen and Japan's Economy, 1985-2008, University of California, Berkeley, https://eml.berkeley.edu/ obstfeld/paper_march09.pdf (10.02.2021).

Park J. (2020), Why the US-led Quad alliance won't realise its 'Asian Nato' ambition against China, "South China Morning Post", https://www.scmp.com/comment/opinion/article/3107469/ why-us-led-quad-alliance-wont-realise-its-asian-nato-ambition (16.02.2021). 
Philip M. (2005), Napoleon and the Invasion of Britain, Bodleian Library, University of Oxford, Oxford.

Projected GDP ranking, https://statisticstimes.com/economy/projected-world-gdp-ranking.php, 20.03.2021.

Rajagopalan R. P. (2020), Towards a Quad-Plus Arrangement?, US-Asia Centre, Perth, https:// perthusasia.edu.au/getattachment/Our-Work/Towards-a-Quad-Plus-Arrangement/PU-160Quad-0421b-WEB.pdf.aspx?lang=en-AU (2.02.2021).

Rosen M. E. (2014), Philippine Claims in the South China Sea: A Legal Analysis, A CNA Occasional Paper, https://www.cna.org/cna_files/pdf/iop-2014-u-008435.pdf (16.02.2021).

Russell C. (2021), Column: China fails to learn from Trump backfire in trade war, is losing against Australia, Reuters, https://www.reuters.com/article/us-column-russell-commodities-chinaaust-idUSKBN29W0HE (16.02.2021).

Sato K. (2019), The Senkaku Islands Dispute: Four Reasons of the Chinese Offensive - A Japanese View, "Journal of Contemporary East Asia Studies", https://www.tandfonline.com/doi/full/ $10.1080 / 24761028.2019 .1626567$ (16.02.2021).

Sediv'y M. (2013), Metternich, the Great Powers and the Eastern Question, University of West Bohemia, Pilsen, http://www.egyptandaustria.at/documents/Metternich,\%20the\%20Great $\% 20$ Powers\%20and\%20the\%20Eastern\%20Question.pdf (10.02.2021).

Smith J. M. (2020), The Quad 2.0: A Foundation for a Free and Open Indo-Pacific, The Heritage Foundation, https://www.heritage.org/sites/default/files/2020-07/BG3481.pdf (19.02.2021).

South Korea: labor productivity 2019, Statista, https://www.statista.com/statistics/642275/southkorea-labor-productivity/ (07.01.2021).

Steinsson S. (2014), John Mearsheimer's Theory of Offensive Realism and the Rise of China, EInternational relations, https://www.e-ir.info/pdf/47402 (24.12.2020).

Suettinger R. L. (2004), The Rise and Descent of "Peaceful Rise", https://www.hoover.org/sites/ default/files/uploads/documents/clm12_rs.pdf(07.01.2021).

Swaine M. D. (2013), Chinese Views Regarding the Senkaku/Diaoyu Islands Dispute, "China Leadership Monitor", No. 41, Hoover Institution, https://www.hoover.org/publications/chinaleadership-monitor/spring-2013 (16.02.2021).

The CIA World Factbook, https://www.cia.gov/library/publications/the-world-factbook/ fields/208rank.html (29.12.2020).

The World Bank data, https://data.worldbank.org/indicator/NY.GDP.MKTP.KD.ZG?locations=CN (12.01.2021).

Turnbull S. (2010), The Mongol Invasion of Japan 1273 and 1281, Osprey Publishing, Oxford, http:// www.siamcostumes.com/cutters_guides/pdf/the-mongol-invasions-of-Japan-1274-and1281-campaign.pdf (01.03.2021).

United States Nonfarm Labour Productivity, 1950-2020 Data, 2021-2023, Forecast https://tradingeconomics.com/united-states/productivity (29.12.2020).

United States Population (2021) - Worldometer, https:/www.worldometers.info/world-population/ us-population/ (07.01.2021).

Waltz K. (2010), Theory of International Politics, Waveland Press, Long Grove.

Wested O. A. (2020), Legacies of the Past In: China and the World, Edited by David Shambaugh, Oxford University Press, Oxford.

World GDP, http://statisticstimes.com/economy/projected-world-gdp-ranking.php (07.01.2021).

World Military Spending, https://www.statista.com/statistics/262742/countries-with-the-highestmilitary-spending/ (24.12.2020). 
Xiaotong W., Anke H., Xingxiang Z., Zhengyao J., Dong W., Fang H., Xijie Y. (2019), Resettlement strategies and Han imperial expansion into southwest China: a multimethod approach to colonialism and migration, "Archaeological and Anthropological Sciences" 11: 6751-6781, Springer, https://link.springer.com/article/10.1007/s12520-019-00938-w (22.02.2021).

Zoellick R. B. (2005), Whither China: From Membership to Responsibility? Remarks to National Committee on U.S.-China Relations, U.S. Department of State Archive, New York City, https://2001-2009.state.gov/s/d/former/zoellick/rem/53682.htm (22.02.2021).

\begin{abstract}
This article aims at adressing several research issues. Firstly, to present offensive realism as a proper research tool to analyse US-China rivalry. Secondly, the author discusses the theory of "China's peaceful rise" and I argues that it smoothly overlapped with the US strategy of liberal hegemony. Thirdly, He presents and defends the argument that China does not rise peacefully. Fourthly, the author claims that China wants to became a regional hegemon in South-East Asia and the USA according to offensive realism cannot let it happen. Last but not least the author considers the arguments that are frequently used to support the theory of "China's peaceful rise" and explains why they fail to depict the current and predict the future nature of US-China relations. In this article the author employed the following research methods: historical, descriptive and decision making methods.
\end{abstract}

Keywords: USA, China, China's peaceful rise, offensive realism

\title{
KONCEPCJA POKOJOWEGO WZROSTU CHIN WEDLUG PARADYGMATU REALISTYCZNEGO
}

\section{STRESZCZENIE}

Ten artykuł ma na celu odniesienie się do kilku zagadnień badawczych. Po pierwsze, przedstawić ofensywny realizm jako odpowiednie narzędzie badawcze do analizy rywalizacji USA-Chiny. Po drugie, autor omawia teorię ,,pokojowego wzrostu Chin” i argumentuje, iż była ona w zasadniczej mierze kompatybilna z amerykańską strategią liberalnej hegemonii. Po trzecie, autor przedstawia i broni argumentu, iż rozwój Chin nie odbywa się pokojowo. Po czwarte, autor twierdzi, że Chiny chcą zostać regionalnym hegemonem w Azji Południowo-Wschodniej, a USA zgodnie z ofensywnym realizmem nie mogą na to pozwolić. Wreszcie autor rozważa argumenty, które są często używane na poparcie teorii „pokojowego wzrostu Chin” i wyjaśnia, dlaczego nie oddają one aktualnego i nie przewidują przyszłego charakteru stosunków USA-Chiny. W artykule zastosowano następujące metody badawcze: historyczną, opisową i decyzyjną.

Słowa kluczowe: USA, Chiny, pokojowy wzrost Chin, ofensywny realizm 